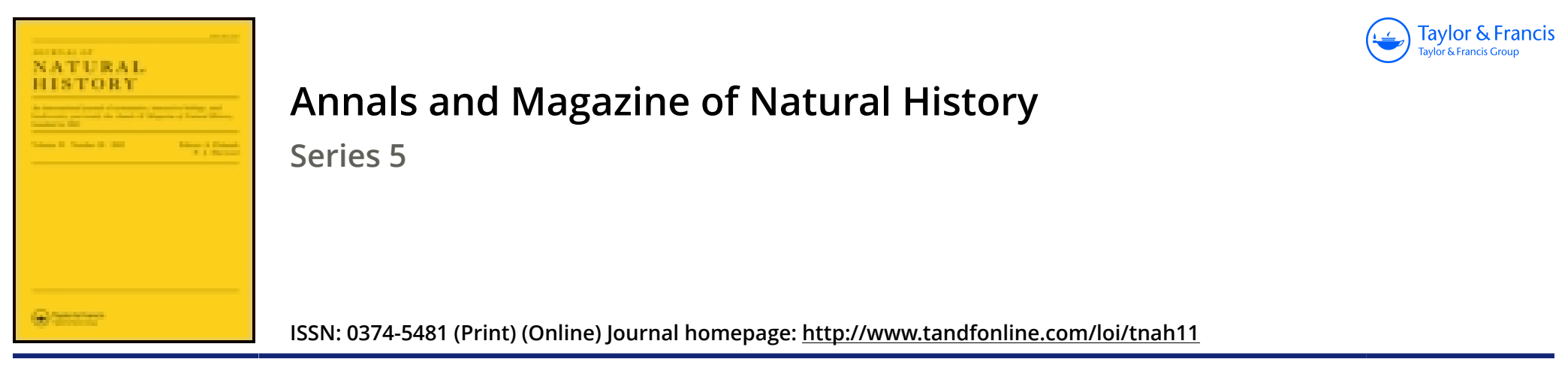

\title{
XXXVII.-Note on Rhacodes inscriptus, Koch, and Armadillo officinalis, Duméril, terrestrial Isopoda
}

\section{Rev. A.E. Eaton M.A.}

To cite this article: Rev. A.E. Eaton M.A. (1882) XXXVII.-Note on Rhacodes inscriptus, Koch, and Armadillo officinalis, Duméril, terrestrial Isopoda , Annals and Magazine of Natural History, 10:59, 360-362, DOI: 10.1080/00222938209459726

To link to this article: http://dx.doi.org/10.1080/00222938209459726

\section{Published online: 07 Oct 2009.}

\section{Submit your article to this journal $\square$}

Џ Article views: 3 
tionship cannot be defined by means of the valves alone without the organs; still less can casts satisfy us in this matter.

With regard to Mr. J. E. Lee's rare little specimens from Devon, in the absence of their valves we can do no more than refer them to the genus Primitia, defined in the Ann. \& Mag. Nat. Hist. ser. 3, vol. xvi. p. 415, and point out that apparently their closest ally is the Lower-Silurian $P$. Barrandiana. It is, however, just possible that, had the casts not been modified by lateral pressure, fig. 1 a might have been much more Leperditioidal and like $P$. Tatei, whilst the posterior convexity in fig. 16 may have been increased, if not brought about, by the same cause. Under these circumstances it is not advisable to venture on a specific determination.

XXXVII.-Note on Rhacodes inscriptus, Koch, and Armadillo officinalis, Dumeril, terrestrial Isopoda. By the Rev. A. E. Eaton, M.A.

Dr. A. Gerstäcker, in a recently published part of Bronn's 'Klassen und Ordnungen des Thier-Reichs,' Bd. v. Abth. ii. p. 209, brackets Rhacodes, Koch, as a synonym of the genus $T y$ los, Latreille. As this combination, if unobjected to, is liable to cause trouble, it may be well to notify that the characters attributed by him to the genus apply in essential particulars to Tylos exclusively.

Rhacodes inscriptus, Koch, described in Rosenhauer's 'Die Thiere Andalusiens,' p. 422 (1856), is a woodlouse very nearly akin to Armadillidium, Brandt and Ratzeburg (1833), judging from the make of its head and antennæ, its tail-segments, their modified legs, and their breathing-organs; and in these distinctive structures it exhibits no affinity with Tylos. Koch's description is sufficient for the recognition of the animal. The most obvious difference between it and Armadillidium is in the eyes : those of this latter genus are multiple, whilst Rhacodes has only a single unfaceted eye on each side of its head. The species was found by Rosenhauer near Malaga at the end of April, not uncommonly. I have met with it in Portugal, near Porto, and at Ponte de Morcellos, in Beira Baixa, at altitudes of from 30 to 600 feet above the sea; also in Madeira, where it is common at altitudes of 2500 5450 feet. In the Hope Museum at Oxford are four examples, collected in the same island by the late Mr. Wollaston, without indications of altitude. 
Tylos, Latr., is thus spelt by every author excepting Dana, U.S. Expl. Exped. xiii. (2) 717, pl. xlvii. 1 (1852), who writes, orthographically, Tylus.

The nomenclature of Armadillo officinalis, Dumeril, seems to demand revision, being utterly corrupt. According as the limits assigned to the genus are large or small, so will its right designation vary; but in no case can it be correctly named Armadillo, Latr. If the genus be restricted to its smallest compass, the name Orthonus, Miers (1877), is valid; but if it be extended to the more comprehensive scope advocated by Dr. Gerstäcker in the place referred to above, it might very justly be called Cubaris, Brandt (1833), enlarged. The genus cannot take the name Armadillo, for two reasons: -first, because this name was preoccupied in zoology for a genus of the Mammalia by Brisson in 1756; secondly, because (if that objection be waired) in Crustacea it can only be applied to the genus described as Armadillo by Latreille in 1804. Now the genus under consideration was unknown to Latreille; the woodlice named by him Armadillo are all without exception species of Armadillidium, Brandt and Ratzeburg (1833); and these joint authors erred in diverting the appellation from that group of species to one which they newly founded on the present animal, previously described as Armadillo officinalis by Duméril in Dict. des Sc. Nat. iii. p. 117 (1816). Simultaneously they altered the name of the species from officinalis to officinarum. In 1835-41 Koch renamed the animal, calling it Pentheus punctatus. The name Penthea, Dej. (1834), in Coleoptera having priority over Pentheus, precludes its adoption in place of Orthonus, Miers, if the restriction of the genus be upheld. The oldest name of the species is Oniscus globator, Cuv., in Journ. d'Hist. Nat. ii. 24 , pl. xxvi. fig. 19 (1792); this will supersede offcinalis, Duméril. Cuvier's figure and description of this woodlouse seem to have been completely forgotten for ninety years.

In the countries bordering upon the Mediterranean Cubaris or Orthonus globator appears to be common at moderate and low altitudes; it is found also upon the principal islands. Beyond that area it abounds in Marocco near Tangier, and is locally plentiful in Western Portugal. In the British Museum are specimens, seemingly of this species, from the Isle of Pines and New Caledonia, and one, possibly identical, from Sikkim ; but these need further examination.

As the present note is virtually a partial criticism of Dr. Gerstäcker's work, I am tempted to cast one more stone at him with respect to his bracketing Haplophthalmus, Schöbl (1860), with Trichoniscus, Brandt (1833), as one genus. 
But the language which it would be necessary to employ would resemble so closely what has been used above touching Rhacodes and Armadillidium, that it might be wearisome to your readers. The qualities of Dr. Gerstäcker's work are too well known to make it necessary to conclude with compliments as a set-off against fault-finding.

Croydon,

October 4, 1882.

XXXVIII.-Spermatozoa, Polygonal Cell-structure, and the Green Colour in Spongilla, together with a nevo Species. By H. J. Carter, F.R.S. \&c.

\section{[Plate XVI.]}

As time progresses so experience throws light upon the nature of objects previously unrealized, and thus, much of what was simply (if correctly) recorded years before may derive explanation from more recent discoveries that have been made public.

When I was studying the freshwater sponges of the tanks in Bombay, about 1850 , Lieberkühn was engaged with those from the river Spree, at Berlin; and although we were both working on the same subject, our facts were differently handled; for while Lieberkühn had for friend and adviser Johannes Müller at Berlin, I not only had no one of the kind at Bombay, but at that time was beholden to others for the loan even of a microscope, so that literally I then felt that all I could do was to describe and delineate faithfully what came before me both for text-book of reference and publication.

Yet was I not altogether without assistance and advice; for at University College, London, I had been educated in part under my kind and dear friends Professors Grant and Sharpey, whose exemplary love of truth stood by me when alone, and has ever kept me in the path of fearless accuracy.

For the purpose of recording my observations, I kept a "journal," in which was not only described, but delineated in colours, every thing that appeared to me worth recording; so that after many years this journal, still continued, often furnishes me with the means of confirming and realizing discoveries which I myself had long since unwittingly madealthough often imperfectly, from the limited power of my microscope.

Thus Mr. Saville Kent, in his excellent 'Manual of the 